\title{
Conservation priorities of useful plants from different techniques of collection and analysis of ethnobotanical data
}

\author{
REINALDO F.P. DE LUCENA ${ }^{1}$, CAMILLA M. LUCENA ${ }^{1}$, ELCIDA L. ARAÚJO ${ }^{2}$, \\ ÂNGELO G.C. ALVES ${ }^{2}$ and ULYSSES P. DE ALBUQUERQUE ${ }^{2}$ \\ ${ }^{1}$ Universidade Federal da Paraíba, Centro de Ciências Agrárias, Departamento de Fitotecnia e Ciências Ambientais, \\ Setor de Ecologia e Biodiversidade, Laboratório de Etnoecologia, Cidade Universitária, 58397-000 Areia, PB, Brasil \\ ${ }^{2}$ Universidade Federal Rural de Pernambuco, Departamento de Biologia, Área de Botânica, \\ Rua Dom Manoel de Medeiros, s/n, Dois Irmãos, 52071-030 Recife, PE, Brasil
}

Manuscript received on July 1, 2011; accepted for publication on September 13, 2011

\begin{abstract}
This study analyzes three methods of data analysis to verify which one would be more appropriate to get information aiming the conservation, selecting the use value (VU) inventory in situ and conservation property index (IPC). It was developed in in Northeast Brazil, via interviewed householders (46 informants). The VU was calculated considering only the effective use of plants; the inventory in situ was made through the frequency of species occurrence in homes; and the IPC combining ethnobotanical and phytossociological data. It was observed a similar cast of the indicated species by VU and inventory in situ, being different from the IPC cast. As this study sought to analyze the best technique for species identification which were needing conservationist actions, and obtained different results among the chosen methods. It has been suggested the use of methods that unite in their analysis both ethnobotanical and ecological aspects, like in the plants list from the priority index of conservation, which demonstrated to be more efficient to identify rare species in the local vegetation. The VU and the inventory in situ are more efficient to identify the most known and used species in the communities, however without analyzing these plants in the local vegetation.
\end{abstract}

Key words: biodiversity, caatinga, inventory in situ, priority index of conservation, use value.

\section{INTRODUCTION}

The destruction of native vegetation areas, and their natural resources, taken severalsciencestofocus their attention in the establishment of areas and priority species for the conservation. The ethnobotany may collaborate with important information about the species situation from the register and knowledge analysis, use and management of plants by local

Correspondence to: Reinaldo Farias Paiva de Lucena

E-mail: reinaldo@cca.ufpb.br population (Kristensen and Balslev 2003, Dalle and Potvin 2004, Lykke et al. 2004, Hanazaki et al. 2006, Florentino et al. 2007, Lucena et al. 2007a, b, 2008), to indicate which areas and group of species require attention for the conservation (Oliveira et al. 2007, Albuquerque et al. 2009). Albuquerque et al. (2009) emphasized the importance that the ethnobotany may have in the conservation of the vegetable diversity, collaborating to design functional and realistic models related to the use of 
vegetable resources. Besides these models, it can also diagnose species which require a gaze upon the conservation through quantitative indexes.

In addition, the hypotheses of ethnobotany being tested also shows the extreme importance of science in the analysis of the current exploitation of useful species, such as the Ecological Apparency Hypothesis, associating the use of local availability. (Albuquerque and Lucena 2005). The advances that ethnobotany has in recent decades in Latin American countries, especially in Brazil, has demonstrated efficiency, competence and professionalism of researchers who conduct research in this area, especially those seeking answers to aid in the conservation of biodiversity. In this perspective, some studies aim to develop techniques that indicate priority species for the local conservation (Dhar et al. 2000, Oliveira et al. 2007, Albuquerque et al. 2009). Most investigations are directly related to the conservation of useful species in local medicine, without considering other uses associated to plants that can be often more harmful than the medical properly (Dhar et al. 2000). Oliveira et al. (2007) reinforce this premise when focus on the importance of the versatility of use of the plants in the analysis of conservation priorities.

From this reality, this study has adapted and tested a conservation priority index (IPC) which includes several categories of local uses of vegetable resources. The IPC was used in other studies like Oliveira et al. (2007) and Dzerefos and Witkowski (2001), being tested in this present study with other techniques of ethnobotanical data analysis: the use value (VU), and the frequency of registered species in an inventory in situ. The choice of the VU to be compared with the IPC was through its frequent use in ethnobotanical studies that have used it as a species indicator with great local importance (Albuquerque et al. 2006, 2009, Oliveira et al. 2007, Lucena et al. 2007a, b). However, some authors have already mentioned the fragility of the use value by failing to distinguish the current use of the resource and its potential use (La TorreCuadros and Islebe 2003, Albuquerque and Lucena 2005, Hoffman and Gallaher 2007). The inventory in situ was chosen because it is a good indicator of current use of the resources, allowing to register the plants that are effectively used by the community (Kvist et al. 2001, Stagegaard et al. 2002, Gavin and Anderson 2005, Gaugris and Van Rooyen 2006, Ramos et al. 2008a, b).

This way, we have attempted to analyze the information offered by different techniques, and the plants list resulting from each one. From that, we sought to identify which species needed conservationist actions. This study verified the rankk each species has shown in the list of the most valuable through the index of VU, in the list of the inventory in situ, and in the list of conservation priority index. Were considered as priority species for conservation those that have excelled in each index, principally those found in more than one. Based in these techniques, it is expected that the indexes purely with ethnobotanical information would reflect a list of plants differentiated from the one obtained through conservation priority index that considered ethnobotanical information associated with data of local availability of the plants.

In this comparison context, this study aims to identify which index would be better applied to studies directed to the conservation of the vegetable diversity found in Caatinga regions, associating and comparing indexes purely ethnobotanical and indexes joining ecological and ethnobotanical information.

\section{MATERIALS AND METHODS}

LOCAL AND REGIONAL CONTEXT OF WORK

The study was developed in semiarid environment in Northeast Brazil, more precisely in rural communities Barrocas and Cachoeira, both located in Soledade city, Paraíba State. Soledade was built by decree $n^{\circ} 171$, September $24^{\text {th }} 1885$, standing in the mesoregion from Agreste and microregion 
from western Curimataú, coordinates $7^{\circ} 03^{\prime} 26^{\prime \prime} \mathrm{S}$ and $36^{\circ} 21^{\prime} 46^{\prime \prime W}$; $180 \mathrm{~km}$ away from João Pessoa, capital city (SEBRAE 1998), being 521 meters above the sea level. It has a territorial area of $560,062 \mathrm{~km}^{2}$, and its population is estimated in 13,128 inhabitants. It has 24,982 hectares of covered areas with native vegetation (SEBRAE 1998).

Soledade has hot semiarid climate (BShs' according to Köppen), with annual precipitation around $300 \mathrm{~mm}$, a short rain season, featuring up to eleven months of drought (Atlas Geográfico do Estado da Paraíba 1985). It presents one of the lowest rainfalls from the Northeast (SEBRAE 1998). Its vegetation is hyperxerophilous shrubby arboreal type, highlighting trees like: Erythrina velutina Wildd. (mulungu), Schinopsis brasiliensis Engl. (baraúna), Ceiba glaziovii (Kuntze) K. Shum (barriguda), and bushes like Aspidosperma pyrifolium Mart. (pereiro), Croton blanchetianus Baill. (marmeleiro) with a great cactus density. Today it is clearly predominant as a result of massive tree deforestation to produce energy, like firewood and coal to be used in homes (SEBRAE 1998). The soil is predominantly halomorphic, with high salinity level, damaging projects for the use of subsurface water (SEBRAE 1998).

\section{STUDIED COMMUNITIES FEATURES}

Two rural communities were selected for this study: Barrocas and Cachoeira. The easy access to them, as well as the proximity to residents, due to other works in the area (Araújo et al. 2005, Lucena et al. 2005, Sá and Silva et al. 2009) were predominant factors in their selection. The community from Barrocas has shown during the execution time of the field work, 12 habitable residential units, predominating private rural properties, and no clustered houses. Corn and bean cultures predominates in the community, being mostly for subsistence. Regarding the livestock, we registered bovine, goat and sheep flocks mostly, with low frequency of poultry and swine. The studied caatinga area showed different faces with the presence of primary vegetation places, secondary vegetation and regeneration areas, represented by cultivation places and abandoned pasture areas. In the sites which are bordered by rivers, streams and ponds, a vegetation with arboreal features was found, while in other places, were registered individuals with shrubby herb size and spaced. Cactus and bromeliad predominance was registered, widely used for animal feed. The area presented intermittent rivers, in which passed a great water volume during "winter time" (local name for rainfall season), mainly in April and May, presenting even sporadic flooding. The bathed areas by rivers had been widely used in the cereal crops and in the cactus forage species, like the ones belonging to Poaceae family.

Differently ofBarrocas, 18 inhabited residential units were found in Cachoeira, particularly village shaped, with divided clusters in the community perimeter, and houses bordering the local road. The community lands are divided between two families. About 14 houses are located at the property of a community. Forest is used by everyone, which possibly allowing a high exploitation pressure on the woody species. According to the older, the tree species were widely consumed in coal production. There are similarities in the agropastoral activities between them. Besides the residences, there are two bars, one soccer field, and one Catholic church being raised, due their local beliefs. As well as in Barrocas, all houses have a cistern to collect drinking water, and a collective one which is supplied by the Brazilian Army, battalion frim the city of Campina Grande. To access the health units, commerce and schools, people from both communities need to go to downtown Soledade (urban area) that isapproximately $12 \mathrm{~km}$ from the beginning of Cachoeira and $15 \mathrm{~km}$ from Barrocas.

Residents from these communities are predominantly farmers, with a subsistence agriculture, not commercial. Besides this activity, men use to work as laborers in farms from the region, and women 
in domestic activities, some as general services assistant in the city schools. In other cases, residents from Cachoeira work in private properties from Barrocas, and women in housework. Generally, they have a low monthly income, in some cases, below the minimum wage. Other income source for them is the retirement of elderly relatives. All belong to families from the region, and live in the lands which have been passed from one generation to another.

\section{COLLECTION OF ETHNOBOtANICAL DATA}

The semi structuralized interviews used in the collection of information for the composition of the priority index of conservation (IPC) and the use value (VU), took place from August 2006 to March 2008, visiting 10 from the 12 residences in Barrocas, and all 18 from Cachoeira. Two residences from Barrocas were not selected in the study as in one of them the informer passed away during the research, and in the other on the informer denied in participating. All heads of family in all houses were interviewed, both man and woman, at separate time (Albuquerque et al. 2010a). Couples were considered as head of families. In Barrocas 17 informers had been interviewed, being nine men and eight women, and 29 in Cachoeira, 13 men and 16 women. Before beginning the interviews, a conversation with each informer was performed to explain the aim of this study. After that, the informer was invited to sign a Term of Free and Clarified Assent, demanded by the Health National Council through the Committee of Ethics in Research (Resolution 196/96).

The form used for the attainment of the data involved questions referring to individuals' knowledge about the use of the plants found in the forests of their community, as well as the collection frequency, also searching socialeconomic information, such as education level, age, occupational activity, monthly income, family composition, time of residence and civil state.
To enrich the acquired information through initial interview, it was applied later the technique of the free list in the utilitarian categories (feeding, fuel, construction, fodder, medicinal, technology, abortive/ poison, veterinary medicine) with main interviewed individuals, being also called key informers. The were recognized through informal colloquies and indications of the communities inhabitants, and confirmed by their specific interviews, in which the amount of the supplied information was analyzed. Six of the 17 informers from Barrocas (four men and two women), and 12 of the 29 from Cachoeira (six men and six women) were selected. After accomplishment of the free list, techniques were applied for its revision and possible enrichment (Brewer 2002, Albuquerque et al. 2010b). For this reason, a new reading was carried out, consisting of a paused reading of mentioned plants list, aiming to rescue the plants forgotten at the first moment of the conversation. Soon after, it has been applied the notspecific induction, which comes from the premise that the informer will be able to remember more plants if questioned through keywords, for example, to ask if more plants with medicinal or nourishing use exist. Finally, the "semantic suggestion", that uses more specific questions to enrich the list, asking themselves if exists another plant in the region with the name similar to those mentioned (Brewer 2002).

The plants mentioned by the interviewed individuals were organized into categories of use adapted from literature (Phillips and Gentry 1993 , Galeano 2000, Albuquerque and Andrade 2002a, b, Ferraz et al. 2006, Lucena et al. 2007a, b). In each one of these categories (feeding, fuel, construction, fodder, medicinal, technology, poison-abortive, veterinary medicine and other uses) subcategories were enclosed indicating the uses that were defined more precisely according to the interviews. For example, in the category "technology", the subcategory "canga" was included (wooden device used in the neck of the animal to lead the carts or croppers), divided in "yoke" of ox cart and 
"canga" of cropper. In the category "other uses", were enclosed the species cited for magic-religious applications and personal hygiene.

\section{INVENTORY OF THE VEGETATION}

To calculate the IPC, this study carried out a phytossociological survey at the Barrocas and Cachoeira communities, gathering information about the frequency and relative density of the woody species of the region, and to register some possible individuals with register of extraction signals. This survey was carried through semi permanent plots of $10 \mathrm{~m} \times 10 \mathrm{~m}$, totalizing 100 plots in each community, making a total area of 1 ha. In the community from Cachoeira, the plots were demarcated in a continuous area. In Barrocas, as that all properties are private, the plots were demarcated in four areas, locating 25 plots in each one of them. These areas were chosen in farms that presented forest fragments, whose owner allowed the inventory's accomplishment. The areas chosen based in the fact that they were areas of resources.

In the inventory, it has been registered all woody individuals which have presented a stem diameter in the ground level (DNS) $\geq$ to $3 \mathrm{~cm}$, being excluded the cactus, small bromeliads, creepers, lianas and small herbaceous (MuellerDumbois and Ellenberg 1974, Araújo and Ferraz 2010). The phytossociological parameters were analyzed according to Araújo and Ferraz (2010): Relative density (DRt, \%), represented in percentage, was estimated by the individuals' number of a determined taxon regarding the total sampled individuals; Relative frequency ( $\mathrm{FRi}, \%)$, was estimated by the percentage of the absolute Frequency of the related species to the Total Frequency. The collected species were identified through comparison with the deposited material in the herbarium Vasconcelos Sobrinho (PEUFR) of the Universidade Federal Rural de Pernambuco, and by consulting the specialists.
USE VAlue

Only the citations of current use were considered in the use value (it only represents all the effective uses of the plants, excluding the known uses, i.e., the ones that are only in people's knowledge, but do not reflect the current use of the plant). This distinction was carried out at the moment of the interviews, when the informant was requested to evidence which species and types of uses were part of their day-byday, uncovering this way the current uses of the plants. The VU was calculated following Rossato et al. (1999): $\mathrm{VU}=\Sigma \mathrm{Ui} / \mathrm{n}$, where $\mathrm{Ui}=$ citation number of use of the species mentioned per each informant, $\mathrm{n}=$ total number of informants.

\section{CONSERVATION PRIORITY INDEX}

For the calculation of the IPC, besides the phytossociological data, this study collected the following ethnobotanical data: the diversity of uses presented for the species and the number of informants who cited determined species. In the IPC, each species received a score representing the sum of all adopted criteria (Table I), being added the ethnobotanical and phytossociological, thus composing a single value. The ethnobotanical criteria were represented by: diversity of uses that each species presented, measured by the amount of uses mentioned for all informants for each one; collection frequency, gotten in the interviews, asking the informant how many times he had incorporated determined plant or its parts; and finally, the local use, represented by the number of informants who had mentioned the effective use of the species. The phytossociological criteria have been represented by the relative frequency and density, and by the signals of selective cut of the individuals. The extraction signals were organized in intact individuals, with sprout, partially cut, total cut, and individuals absent in the inventory of the vegetation.

The changes in the calculation of the IPC were carried out from the formula proposed by Oliveira et al. (2007), that refers to changes in the 
percentage of the number of informants who had mentioned citations for the species; the collection risks substituted the parts used by extraction signals in the individual, it was added in the index scores referring to the frequency of collection and the relative frequency.

INVENTORY IN SITU

An inventory in situ (according to Medeiros et al. 2010) was performed in the residences of the two communities aiming to identify the species used by people at the moment of the visit (see examples in Kvist et al. 2001, Stagegaard et al. 2002, Gavin and Anderson 2005). The information acquired with this technique had been used in the identification of possible species that deserve special attention regarding the conservation.

The inventory happened at two moments with interval of 30 days between the months of March and April 2008. This interval was considered to enrich the survey after the first visit. At the moment of the visits, al visualized uses were registered by the researcher in the residence that had a relation the woody and native species. The information of the two visits composed a single evaluation in the data analysis, based in the frequency and presence of the species or object of vegetal origin in the residences. In this stage, with the aid of the informer, the species found in the residence or the materials of vegetal origin, or part of a plant that was to be used, were recognized by the vernacular name. After that, with the informer who had a guided tour, the same species were searched in the vegetation for collection and botanical identification.

In the fuel category, were registered all plants visualized in the firewood supply and in reservoir of the firewood domestic stoves, that were identified with the contribution of the informants. In the construction category, the species used in the agricultural and domestic construction. In the domestic construction, it was observed the use of the species in the object manufacture for the construction of houses as beams, tie beams, laths, doors and windows, and other constructions in the property. In the agricultural construction, the plants that were in the fences composition that delimited the houses, poles, prop and fencepost, and those used in the gates manufacture. The medicinal plants and the ones with veterinarian use were registered through visualization of manufactured remedies or parts of the collected plant with this purpose. In the category technology, were registered the species that have served for making the tool handles, kedge for water transport, the yokes used in the carts and croppers, and other uses of technological character.

\section{DATA ANALYSIS}

\section{Calculus of the conservation priority index}

The IPC has been calculated according to the formula:

$$
\mathrm{IPC}=\mathrm{UL}+\mathrm{DU}+\mathrm{IF}+\mathrm{FCE}+\mathrm{DR}+\mathrm{FR},
$$

where: UL represents the number of informants who cited the plant for any purpose; DU, the number of uses that were attributed to the species; SE represents the types of extractive signals that were visualized in the individuals of the sampling areas; $\mathrm{FC}$, the frequency that each species is collected by the informer; FR, the relative frequency and DR, the relative density of the phytossociological survey. SE and the FC were considered the greatest scores, since the same species could fit in more than one value (example: weekly collection and annual collection). To verify a relation between the different used quantitative measures (VU, IPC and frequency in the inventory in situ), the correlation coefficient of Spearman (Zar 1996) was used through the software BioEstat 5.0 (Ayres et al. 2003). It was also used the non-parametric test of Kruskal-Wallis to verify if it there were differences between the communities according to values of each index (VU, frequency in the inventory in situ and IPC). For this test, were considered only the species that appeared simultaneously in the two communities. 
TABLE I

Scores used for the analysis of the conservation priority index (IPC) of the vegetation in the study area telling the local use (citation number of real use), use diversity, extraction signals, collection frequency, collected amount, density and frequency of the species (modified of Oliveira et al. 2007).

\begin{tabular}{|c|c|}
\hline Criteria & Scores \\
\hline \multicolumn{2}{|l|}{$\begin{array}{l}\text { A. Local use ( } n^{\circ} \text { of informants Who have } \\
\text { cited the real use of the species) (UL) }\end{array}$} \\
\hline \multicolumn{2}{|l|}{$(\mathbf{U L})$} \\
\hline High (listed by $>71 \%$ of the local informants) & 10 \\
\hline Moderately high $(41 \% \leq 70 \%$ of the local informants) & 7 \\
\hline Moderately low ( $0 \% \leq 40 \%$ of the local informants) & 4 \\
\hline \multicolumn{2}{|l|}{ B. Diversity of use (DU) } \\
\hline For each use is added a point for the maximum of 10 & $1-10$ \\
\hline \multicolumn{2}{|l|}{ C. Extraction Signals (SE) } \\
\hline Intact individuals (without signal of extraction cut) & 1 \\
\hline Individuals with regrowth & 3 \\
\hline $\begin{array}{l}\text { Individuals partially cut (only part of } \\
\text { the individual is cut) }\end{array}$ & 5 \\
\hline Individuals cut ( $100 \%$ of the individual cut) & 7 \\
\hline Individuals without phytossociological register & 10 \\
\hline \multicolumn{2}{|l|}{ D. collection frequency (FC) } \\
\hline Sporadic Collection & 1 \\
\hline Collection over 10 years & 2 \\
\hline Collection between 05 to 10 years & 3 \\
\hline Collection between 01 to 05 years & 4 \\
\hline Annual collection & 5 \\
\hline Biannual collection & 6 \\
\hline Quaterly collection & 7 \\
\hline Monthly Collection & 8 \\
\hline Weekly collection & 9 \\
\hline Daily collection & 10 \\
\hline \multicolumn{2}{|l|}{ E. Relative Density (DR) } \\
\hline Not registered - very low $(0-1)$ & 10 \\
\hline Low $(1<3.5)$ & 7 \\
\hline Medium $(3.5<7)$ & 4 \\
\hline $\operatorname{High}(\geq 7)$ & 1 \\
\hline \multicolumn{2}{|l|}{ F. Relative Frequency (FR) } \\
\hline Not registered - very low $(0-1)$ & 10 \\
\hline Low $(1<3.5)$ & 7 \\
\hline Medium $(3.5<7)$ & 4 \\
\hline $\operatorname{High}(\geq 7)$ & 1 \\
\hline
\end{tabular}

The species which were registered in the inventory of the vegetation and in the interviews with the inhabitants of the community received scores for achieved values in the value index of use, inventory in situ and in the conservation priority index. From these scores, were separated the ten species that received the biggest values (Tables III, IV and V). These tables have information about the values of each index, being added the indications of the use categories (Table V) of each species, as well as data on its availability in the vegetation. In the triangulation of the list of the three indexes, it has 20 species indicated for the conservation priority in Cachoeira and 15 in Barrocas. Each technique has shown exclusive species.

\section{RESULTS}

\section{COMMUNITY 1: BARROCAS}

In the community of Barrocas, were registered 44 woody plants known by the vernacular name, of which 41 have been identified, as belonging to the 16 families (Table II). The inventory of the vegetation still disclosed signals of selective cut in some individuals of determined species. The observed signals were recognized as: totally cut individuals, partially cut and with sprout signals. The species that have registered at least one of these signals were Aspidosperma pyrifolium C. Mart., Bauhinia cheilantha (Bong.) Steud., Poincianella pyramidalis Tul., Commiphora leptophloeos (Mart.) J.B. Gillet., Croton blanchetianus Baill., Croton sincorensis Mart. ex Müll. Arg., Jatropha mollissima (Pohl) Baill., Manihot dichotoma Ule, Mimosa ophthalmocentra Mart. ex Benth., Mimosa tenuiflora (Willd.) Poir., Myracrodruon urundeuva Allemão, Piptadenia stipulaceae (Benth.) Ducke, Schinopsis Brasiliensis Engl. This comment became important for the visualization of the species that showed pressure signals of use in the forest, being important in possible indications of species with local conservation priority. 
TABLE II

Ranking of species of greater local importance, second highest use value (VU), the frequency in inventory in situ and conservation priority index (IPC) in the communities of Barrocas and Cachoeira in the municipality of Soledade, Northeast Brazil.

\begin{tabular}{|c|c|c|c|c|c|c|c|}
\hline \multirow{2}{*}{ Species } & \multirow{2}{*}{$\begin{array}{l}\text { Vernacular } \\
\text { name }\end{array}$} & \multirow{2}{*}{$\begin{array}{c}\text { VU } \\
\text { Cachoeira }\end{array}$} & \multirow{2}{*}{$\begin{array}{c}\text { VU } \\
\text { Barrocas }\end{array}$} & \multicolumn{2}{|c|}{ Inventory in situ (\%) } & \multicolumn{2}{|c|}{$\operatorname{IPC}(\Sigma)$} \\
\hline & & & & Cachoeira & Barrocas & Cachoeira & Barrocas \\
\hline \multicolumn{8}{|l|}{ ANACARDIACEAE } \\
\hline Myracrodruon urundeuva Allemão & aroeira & 1.59 & 1.29 & 82.35 & 100 & 48 & 46 \\
\hline Schinopsis brasiliensis Engl. & baraúna & 0.76 & 0.41 & 23.53 & 90 & 45 & 36 \\
\hline Spondias tuberosa Arruda & umbuzeiro & 1.52 & 1.76 & 35.29 & 30 & 38 & 30 \\
\hline \multicolumn{8}{|l|}{ APOCYNACEAE } \\
\hline Aspidosperma pyrifolium C.Mart. & pereiro & 3.72 & 3.12 & 100 & 100 & 36 & 37 \\
\hline \multicolumn{8}{|l|}{ BOMBACACEAE } \\
\hline Ceiba glaziovii (Kuntze) K. Schum & barriguda & 0.10 & 0.06 & 0 & 0 & 41 & 36 \\
\hline $\begin{array}{l}\text { Pseudobombax marginatum (A.St.- } \\
\text { Hil.,Juss.\& Cambess.) A. Robyns }\end{array}$ & imbiratã & 0.24 & 0.12 & 17.65 & 0 & 45 & 18 \\
\hline \multicolumn{8}{|l|}{ BURSERACEAE } \\
\hline $\begin{array}{l}\text { Commiphora leptophloeos } \\
\text { (Mart.) J. B. Gillet }\end{array}$ & umburana & 1.41 & 0.94 & 82.35 & 90 & 44 & 43 \\
\hline \multicolumn{8}{|l|}{ CAPPARACEAE } \\
\hline Cynophalla flexuosa (L.) L. & feijão brabo & 0.59 & 1.00 & 35.29 & 60 & 40 & 30 \\
\hline \multicolumn{8}{|l|}{ CELASTRACEAE } \\
\hline Maytenus rigida Mart. & bom nome & 0.62 & 0.29 & 5.88 & 10 & 53 & 23 \\
\hline \multicolumn{8}{|l|}{ COMBRETACEAE } \\
\hline Thiloa glaucocarpa (Mart.) Eichler & joão mole & 0.28 & 0.00 & 0 & 0 & 44 & 30 \\
\hline \multicolumn{8}{|l|}{ EUPHORBIACEAE } \\
\hline Cnidoscolus quercifolius Pohl & favela & 0.38 & 0.35 & 17.65 & 0 & 54 & 41 \\
\hline Croton blanchetianus Baill. & marmeleiro & 2.10 & 1.82 & 82.35 & 100 & 36 & 35 \\
\hline Croton heliotropiifolius Kunth & quebra faca & 0.21 & 0.12 & 11.76 & 10 & 49 & 21 \\
\hline Croton rhamnifolius Kunth & velame & 0.03 & 0.00 & 5.88 & 0 & 36 & 30 \\
\hline $\begin{array}{l}\text { Croton sincorensis } \\
\text { Mart. Ex Müll. Arg. }\end{array}$ & $\begin{array}{l}\text { marmeleiro } \\
\text { branco }\end{array}$ & 0.03 & 0.00 & 5.88 & 0 & 38 & 21 \\
\hline Jatropha mollissima (Pohl) Baill. & pinhão brabo & 0.28 & 0.12 & 82.35 & 10 & 27 & 23 \\
\hline Jatropha ribifolia (Pohl) Baill. & pinhão manso & 0.00 & 0.00 & 5.88 & 0 & 10 & 12 \\
\hline Manihot dichotoma Ule & maniçoba & 0.14 & 0.12 & 58.82 & 10 & 19 & 13 \\
\hline Sapium lanceolatum (Müll.Arg.) Huber & burra leiteira & 0.00 & 2.35 & 5.88 & 0 & 30 & 14 \\
\hline \multicolumn{8}{|l|}{ FABACEAE } \\
\hline Anadenanthera colubrina (Vell.) Brenan & angico & 0.38 & 0.12 & 17.65 & 20 & 48 & 25 \\
\hline Amburana cearensis (Allemão) A.C.Sm. & cumaru & 0.38 & 0.35 & 11.76 & 10 & 27 & 41 \\
\hline Bauhinia cheilantha (Bong.) Steud. & Mororó & 0.72 & 0.29 & 23.53 & 0 & 52 & 29 \\
\hline $\begin{array}{l}\text { Chloroleucon mangense (Jacq.) Britton } \\
\text { \& Rose }\end{array}$ & coronha braba & 0.03 & 0.00 & 0 & 0 & 36 & 30 \\
\hline Erythrina velutina Willd. & mulungu & 0.38 & 0.12 & 29.41 & 30 & 49 & 21 \\
\hline $\begin{array}{l}\text { Senna martiana (Benth.) H.S. Irwin } \\
\text { Barneby }\end{array}$ & canafistula & 0.00 & 0.00 & 5.88 & 10 & 30 & 30 \\
\hline $\begin{array}{l}\text { Libidia ferrea (Mart. ex Tul.) L. P. } \\
\text { Queiroz }\end{array}$ & jucá & 0.17 & 0.35 & 0 & 10 & 40 & 27 \\
\hline
\end{tabular}


TABLE II (CONTINUATION)

\begin{tabular}{|c|c|c|c|c|c|c|c|}
\hline \multirow{2}{*}{ Species } & \multirow{2}{*}{$\begin{array}{l}\text { Vernacular } \\
\text { name }\end{array}$} & \multirow{2}{*}{$\begin{array}{c}\text { VU } \\
\text { Cachoeira }\end{array}$} & \multirow{2}{*}{$\begin{array}{c}\text { VU } \\
\text { Barrocas }\end{array}$} & \multicolumn{2}{|c|}{ Inventory in situ (\%) } & \multicolumn{2}{|c|}{ IPC $(\Sigma)$} \\
\hline & & & & Cachoeira & Barrocas & Cachoeira & Barrocas \\
\hline \multicolumn{8}{|l|}{ FABACEAE } \\
\hline $\begin{array}{l}\text { Mimosa ophthalmocentra Mart. ex } \\
\text { Benth. }\end{array}$ & $\begin{array}{l}\text { jurema de } \\
\text { imbira }\end{array}$ & 0.59 & 1.06 & 64.71 & 90 & 38 & 33 \\
\hline Mimosa tenuiflora (Willd.) Poir. & jurema preta & 0.86 & 1.24 & 82.35 & 50 & 44 & 34 \\
\hline Piptadenia stipulaceae (Benth.) Ducke & jurema branca & 0.38 & 0.65 & 35.29 & 20 & 38 & 33 \\
\hline Poincianella pyramidalis Tul. & catingueira & 2.24 & 2.35 & 88.24 & 100 & 39 & 38 \\
\hline \multicolumn{8}{|l|}{ MYRTACEAE } \\
\hline Eugenia uvalha Cambess. & ubaia & 0.03 & 0.00 & 0 & 0 & 40 & 30 \\
\hline \multicolumn{8}{|l|}{ OLACACEAE } \\
\hline Ximenia americana $\mathrm{L}$. & ameixa & 0.86 & 0.59 & 0 & 10 & 55 & 46 \\
\hline \multicolumn{8}{|l|}{ RHAMNACEAE } \\
\hline Ziziphus joazeiro Mart. & juazeiro & 0.66 & 0.76 & 11.76 & 30 & 43 & 43 \\
\hline \multicolumn{8}{|l|}{ SAPOTACEAE } \\
\hline $\begin{array}{l}\text { Sideroxylon obtusifolium (Roem. \& } \\
\text { Schult.) T.D.Penn. }\end{array}$ & quixabeira & 1.76 & 2.06 & 58.82 & 60 & 52 & 39 \\
\hline \multicolumn{8}{|l|}{ UNIDENTIFIED } \\
\hline Specie 1 & ingai & 0.07 & 0.76 & 0 & 0 & 32 & 30 \\
\hline Specie 2 & louro & 0.86 & 0.12 & 5.88 & 0 & 30 & 37 \\
\hline
\end{tabular}

Analyzing the list of the species ordered by these techniques, a sharing of nine species was observed between the use value and the inventory in situ. However, the same species positioned themselves in a different rank in each index; for example Sideroxylon obtusifolium (Gnaws. \& Schult.) T.D. Penn. that occupied the third position in the use value, and eighth in the inventory in situ. A. Pyrifolium and P. pyramidalis stood out in the two lists occupying the first positions.

The fact that $S$. tuberosa was not registered among the ten more important species in the inventory in situ, despite its great local importance as nourishing, it was due the period in which the visits occurred, performing the inventory out of its fruition period. This species begins its fruition period, generally, from December to March. However, the two moments in which the inventory in situ was performed were in different period. The case of $S$. brasiliensis did not stand out in the list of the use value to its use being of potential character, and not usual. In other words, this species showed some uses, but not necessarily used.

The comparison of the use value with the conservation priority index demonstrated a bigger difference in the composition of the top ten list of the more important species, being shared only five. In the list presented by the IPC, the exclusive species are considered scarce in the community, like Cnidoscolus quercifolius Pohl and American Ximenia L. This may be explained by their low availability in the forest. For this reason, they received a high score in each phytossociological parameter used in the IPC, and for being recognized as species of multiple uses in the medicine and veterinary medicine in the community. On the other hand, the fact that $C$. blanchetianus did not evidence among the most important in the IPC, appearing only in the use value, is explained by its wide distribution in the forests, getting so low scores in the IPC. In the analysis between the inventory in situ and the conservation priority 
index, they shared five species that were evidenced in the three lists, being them A. pyrifolium, $P$. pyramidalis, S. obtusifolium, M. urundeuva and $C$. leptophloeos. In the case of the exclusive species in the order of the IPC, for example, Ziziphus joazeiro Mart. and Amburana cearensis (Allemão) A.C.Sm., can be explained by the same principle presented regarding the $C$. quercifolius and $X$. americana.

There was a high correlation between the use value and the frequency in the inventory in situ (rs $=0.71 ; \mathrm{p}<0.0001)$, so the species that stood out tend to be the same for both indexes. Regarding the conservation priority index and the other indexes, there was correlation, but low and not significant (VU and the IPC $-\mathrm{rs}=0.15 ; \mathrm{p}>0.05$ ); frequency in the inventory in situ and the IPC - $\mathrm{rs}=0.24 ; \mathrm{p}>0.05$ ). The correlation presented between the use value and the inventory in situ was foreseeable due to the actual use of the species had been analyzed, differing from the conservation priority index that involved other parameters in its calculation, such as availability in the vegetation, collection frequency and diversity of uses, which influenced in the low correlation.

Analyzing the group of the ten more important species achieved by each technique adopted in this study, the ones that deserve more local conservationist attention are those that presented greater values in each one of them. In Barrocas the ones which require bigger attention are: $A$. pyrifolium, $P$. pyramidalis, S. obtusifolium, $M$. urundeuva and Commiphora leptophloeos, being them highlighted for the three indexes. From these species, A. pyrifolium, $P$. pyramidalis and $C$. leptophloeos are widely found in the forests. $M$. urundeuva and S. obtusifolium must be observed with more attention, because they have few individuals in the vegetation, being highly valued in the three indexes.

Besides these species, some that were not registered in the list of ten more important in the three techniques, but deserve a special attention due its medicinal use and its scarcity in the forests are Bauhinia cheilantha (Bong.) Steud., Anadenanthera colubrina (Vell.) Brenan and Maytenus rigida Mart. They received high use values, when considered only its medicinal attributes, although to have received less values when considered all the categories. This happened, because when congregated all the use citations the species tend to have its use value diluted.

\section{COMMUNITY 1: CACHOEIRA}

In the community from Cachoeira, it has been registered 44 woody plants known by the vernacular name, of which 41 were identified, as belonging to the 16 families (Table II). The inventory of the vegetation still has disclosed signals of selective cut in some individuals of determined species. The observed signals have been recognized as: totally cut individuals, partially cut and with sprout signals. The species that registered at least one of these signals were Aspidosperma pyrifolium C. Mart., Poincianella pyramidalis Tul., Croton blanchetianus Baill., Jatropha mollissima (Pohl) Baill., Mimosa ophthalmocentra Mart. ex Benth., Mimosa tenuiflora (Willd.) Poir., Myracrodruon urundeuva Allemão, Piptadenia stipulaceae (Benth.) Ducke and Schinopsis brasiliensis Engl. As in Barrocas, this observation became important for visualization of the species that showed signs of pressure used in the forest, these are important indications of possible species conservation priority site.

Analyzing the list of the species ordered in the use value and in the inventory in situ, it is possible to observe seven being shared (Table III). A. pyrifolium was the first one placed in the two techniques, and P. pyramidalis the second. The other species alternated its positioning. Thus, as it happened in Barrocas, $S$. tuberosa was evidenced in the order of the use value, being absent of the inventory in situ due the accomplishment period of the survey. In the inventory in situ, were highlighted $J$. mollisma and M. dichotoma for their use in the construction of fences. 
TABLE III

Values of second greater important species use value (VU), the inventory in situ and conservation priority index (IPC) in the community of Barrocas, the municipality of Soledade, Paraiba, Brazil. Where: IPC = index of conservation priority, $\mathrm{VU}=$ use value; IN SITU = percentage of species in inventory situ; NI = number of individuals registered in phytosociology; $\mathrm{RD}=$ relative density, $\mathrm{RF}$ = relative frequency; $\mathrm{CU}=$ categories use. In the categories of use we have: ct $=$ construction; fo = food; $\mathrm{fr}=$ forage; $\mathrm{fu}=$ fuel; $\mathrm{me}=$ medical; $\mathrm{tc}=$ technology; $\mathrm{vt}=$ veterinarian, or $=$ other uses.

\begin{tabular}{|c|c|c|c|c|c|c|c|}
\hline Species & IPC & $\mathbf{V U}$ & IN SITU & NI & DR & FR & $\mathbf{C U}$ \\
\hline Amburana cearensis (Allemão) A.C.Sm. & 41 & 0.35 & $10 \%$ & 0 & 0 & 0 & me,vt \\
\hline Aspidosperma pyrifolium C. Mart. & 37 & 3.12 & $100 \%$ & 555 & 16.53 & 16.30 & fr, fu,ct,tc.vt \\
\hline Cynophalla flexuosa (L.) L. & 30 & 1 & $60 \%$ & 4 & 0.12 & 0.72 & $\mathrm{fr}, \mathrm{tc}, \mathrm{vt}$ \\
\hline Cnidoscolus quercifolius Pohl & 41 & 0.35 & $20 \%$ & 0 & 0 & 0 & me,vt \\
\hline Commiphora leptophloeos (Mart.) Gillet. & 43 & 0.94 & $90 \%$ & 6 & 0.18 & 1.09 & $\mathrm{ct}, \mathrm{me}, \mathrm{tc}, \mathrm{vt}$ \\
\hline Croton blanchetianus Baill. & 35 & 1.82 & $100 \%$ & 1.618 & 48.18 & 16.85 & $\mathrm{fr}$, fu,ct,me \\
\hline Mimosa ophthalmocentra Mart ex Benth. & 33 & 1.06 & $90 \%$ & 96 & 2.86 & & fr, fu,ct,tc \\
\hline Mimosa tenuiflora (Willd.) Poir. & 34 & 1.24 & $50 \%$ & 27 & 0.80 & 3.62 & fr, fu,ct \\
\hline Myracrodruon urundeuva Allemão & 46 & 1.29 & $100 \%$ & 3 & 0.09 & 0.54 & $\mathrm{fr}, \mathrm{fu}, \mathrm{ct}, \mathrm{me}, \mathrm{vt}$ \\
\hline Poincianella pyramidalis Tul. & 38 & 2.35 & $100 \%$ & 597 & 17.78 & 17.93 & $\mathrm{fr}$, fu,ct,me \\
\hline Schinopsis brasiliensis Engl. & 36 & 0.41 & $90 \%$ & 14 & 0.42 & 1.99 & fr, fu,ct,vt \\
\hline $\begin{array}{l}\text { Sideroxylon obtusifolium } \\
\text { (Roem. \& Schult.) T.D. Penn. }\end{array}$ & 39 & 2.06 & $60 \%$ & 1 & 0.03 & 0.18 & fo,fr,me,tc, vt \\
\hline Spondias tuberosa Arruda & 30 & 1.76 & $30 \%$ & 1 & 0.03 & 0.18 & fo,fr, fu,me \\
\hline Ximenia americana $\mathrm{L}$. & 46 & 0.59 & $10 \%$ & 0 & 0 & 0 & me \\
\hline Ziziphus joazeiro Mart. & 43 & 0.76 & $30 \%$ & 0 & 0 & 0 & fo,fr,me,vt \\
\hline
\end{tabular}

The comparison of the use value with the conservation priority index demonstrated an outstanding difference in the composition of the ten more important species, sharing only three. Following in Cachoeira the same standard of the IPC list from Barrocas, the exclusive ones are considered scarce in the community, as $C$. quercifolius, $X$. Americana, $M$. rigida, $B$. cheilantha, Erithrina velutina Willd. A. colubrina and the Croton heliotropifolius Kunth. This fact can be explained by the low local availability of these species in the vegetation.

In the analysis between the inventory in situ and the conservation priority index, they shared only two species that evidenced in the three lists: $S$. obtusifolium and M. urundeuva. The other species of the IPC list were exclusive to it.

In Cachoeira there was a high correlation between the VU and the frequency in the inventory in situ ( $\mathrm{rs}=0.67 ; \mathrm{p}<0.0001)$. However, different from Barrocas, there was a weak, but significant correlation between the VU and the IPC in Cachoeira ( $r s=0.43 ; p<0.01$ ). The IPC and the frequency in the inventory in situ did not show significant correlation ( $\mathrm{rs}=0.11$; $p>0.05)$. The explanation for the scenario of these correlations is the same one presented to Barrocas' community.

In Cachoeira the same principle observed in the community of Barrocas was applied, the species evidenced by the three indexes were $S$. obtusifolium and M. urundeuva. The use value and the conservation priority index indicated especially $X$. Americana. These species are found scarcely in the community vegetation, with individuals very spaced and distant from each other, making them objects of conservationist measures.

The species indicated using the information of the use value and the inventory in situ as priority for the conservation were A. pyrifolium, $P$. 
pyramidalis and C. blanchetianus. These species were highlighted in both for being widely used in the community, mainly as firewood in the domestic stoves, for its great availability in the vegetation.

\section{COMPARING THE STUDIED COMMUNITIES}

Analyzing the list of the species in the use value of the two communities, a sharing of five from the ten more valued is feasible. The conservation priority index shared four and inventory in situ, eight. A comparison was performed among the lists of the most important species from the three indexes in the two communities through Kruskal-Wallis test to verify if there were differences between the two communities. However, it evidenced that there were no differences between the two communities, both for the use value $(\mathrm{H}=0.04$; $\mathrm{p}$ $>0.05)$, as for the frequency in the inventory in situ $(\mathrm{H}=0.98 ; \mathrm{p}>0.05)$. For the IPC, there were significant differences between them $(\mathrm{H}=14.00$;

TABLE IV

Ranking of the ten species of greater local importance, the second highest use value (VU), the frequency in inventory in situ and conservation priority index (IPC) in the communities of Barrocas and Cachoeira in the municipality of Soledade, Paraiba, Brazil.

\begin{tabular}{|c|c|c|c|c|c|c|}
\hline \multirow{2}{*}{ Species } & \multicolumn{3}{|c|}{ Barrocas } & \multicolumn{3}{|c|}{ Cachoeira } \\
\hline & VU general & Freq. in situ & IPC & VU general & Freq. in situ & IPC \\
\hline Amburana cearensis (Allemão) A.C.Sm. & & & $5 \mathrm{st}$ & & & \\
\hline Anadenanthera colubrina (Vell.) Brenan & & & & & & $8 \mathrm{st}$ \\
\hline Aspidosperma pyrifolium Mart. & $1 \mathrm{st}$ & 1 st & 10 st & $1 \mathrm{st}$ & $1 \mathrm{st}$ & \\
\hline Bauhinia cheilantha (Bong.) Steud. & & & & & & 4 st \\
\hline Cyanophalla flexuosa (L.) L. & 9 st & 8 st & & & & \\
\hline Cnidoscolus quercifolius Pohl & & & $5 \mathrm{st}$ & & & 2nd \\
\hline Commiphora leptophloeos (Mart.) Gillet. & $10 \mathrm{st}$ & 5 st & $3 \mathrm{rd}$ & $7 \mathrm{st}$ & 3 rd & \\
\hline Croton blanchetianus Baill. & 4 st & $1 \mathrm{st}$ & & $3 r d$ & $3 r d$ & \\
\hline Croton heliotropiifolius Kunth. & & & & & & 6 st \\
\hline Erythrina velutina Willd. & & & & & & 6 st \\
\hline Jatropha mollissima (Pohl) Baill. & & & & & 3 rd & \\
\hline Manihot dichotoma Ule & & & & & 9 st & \\
\hline Maytenus rigida Mart. & & & & & & 3 rd \\
\hline Mimosa ophthalmocentra Mart ex Benth. & 8 st & $5 \mathrm{st}$ & & & $8 \mathrm{st}$ & \\
\hline Mimosa tenuiflora (Willd.) Poir. & $7 \mathrm{st}$ & 10 st & & 8 st & $3 r d$ & \\
\hline Myracrodruon urundeuva Allemão & 6 st & 1 st & 1 st & $5 \mathrm{st}$ & $3 r d$ & 8 st \\
\hline Parkinsonia aculeata $\mathrm{L}$. & & & $7 \mathrm{st}$ & & & \\
\hline $\begin{array}{l}\text { Pseudobombax marginatum } \\
\text { (A.St.-Hil., Juss.\& Cambess.) A. Robyns }\end{array}$ & & & & & & 10 st \\
\hline Poincianella pyramidalis Tul. & 2nd & 1 st & 9 st & 2nd & 2nd & \\
\hline Schinopsis brasiliensis Engl. & & 5 st & & & & 10 st \\
\hline Sideroxylon obtusifolium (Roem. \& Schult.) T.D. Penn. & $3 r d$ & 8 st & 8 st & 4 st & 9 st & 4 st \\
\hline Spondias tuberosa Arruda & $5 \mathrm{st}$ & & & 6 st & & \\
\hline Ximenia americana L. & & & $1 \mathrm{st}$ & 8 st & & $1 \mathrm{st}$ \\
\hline Ziziphus joazeiro Mart. & & & $3 r d$ & & & \\
\hline Unidentified 1 (louro) & & & $10 \mathrm{st}$ & 8 st & & \\
\hline
\end{tabular}


$\mathrm{p}<0.05$ ), and in the community from Cachoeira the species showed greater values of IPC than the those from Barrocas. The fact that the IPC in Cachoeira presented higher values than the ones from Barrocas can be explained by the higher availability of the species in the forests from Barrocas, and because the number of informers were bigger in Cachoeira, which may have also increased the scores of the collection frequency, diversity of use, and number of informants who had mentioned use for the species.
In the comparison of the list of the ten species with higher values presented by the three indexes in the two communities, two were shared among all of them: S. obtusifolium and M. urundeuva. When compared only the list presented per each index, it has the following situation: eight species shared by the value of use and the inventory in situ, and in the conservation priority index four (see Table III), two of which are rarely found in the two communities, for this reason, they received special attention, being them $X$. americana and C. quercifolius.

TABLE V

Values of second greater important species use value (VU), the inventory in situ and conservation priority index (IPC) in the community of Cachoeira, the municipality of Soledade, Paraiba, Brazil. Where: IPC = index of conservation priority, $\mathrm{VU}=$ use value; IN SITU = percentage of species in inventory situ; $\mathrm{NI}=$ number of individuals registered in phytosociology; $\mathrm{RD}=$ relative density, $\mathrm{RF}=$ relative frequency; $\mathrm{CU}=$ categories use. In the categories of use we have: ct $=$ construction; fo = food $; \mathrm{fr}=$ forage $; \mathrm{fu}=$ fuel; me $=$ medical; tc $=$ technology vt $=$ veterinarian, or $=$ other $u$ uses.

\begin{tabular}{|c|c|c|c|c|c|c|c|}
\hline Species & IPC & $\mathbf{V U}$ & IN SITU & NI & DR & $\mathbf{F R}$ & $\mathbf{C U}$ \\
\hline Anadenanthera colubrina (Vell.) Brenan & 54 & 0.38 & $17.65 \%$ & 0 & 0 & 0 & fu,ct,fr, \\
\hline Aspidosperma pyrifolium C. Mart. & 36 & 3.72 & $100 \%$ & 423 & 10.92 & 21.06 & fr,fu,ct,tc, vt \\
\hline Bauhinia cheilantha (Bong.) Steud. & 58 & 0.72 & $23.53 \%$ & 0 & 0 & 0 & fr,me,vt \\
\hline Cnidoscolus quercifolius Pohl & 60 & 0.38 & $17.65 \%$ & 0 & 0 & 0 & fr,me,vt \\
\hline Commiphora leptophloeos (Mart.) Gillet. & 47 & 1.41 & $82.35 \%$ & 3 & 0.08 & 0.67 & fr,fu,ct,me,vt,tc \\
\hline Croton blanchetianus Baill. & 36 & 2.10 & $82.35 \%$ & 1821 & 47.01 & 22.17 & fr,fu,ct, \\
\hline Croton heliotropiifolius Kunth. & 38 & 0.03 & $11.76 \%$ & 0 & 0 & 0 & fu,ct,me, \\
\hline Erythrina velutina Willd. & 55 & 0.38 & $29.41 \%$ & 0 & 0 & 0 & fr,ct,me,vt \\
\hline Jatropha mollissima (Pohl) Baill. & 33 & 0.28 & $82.35 \%$ & 370 & 9.55 & 19.96 & ct,me \\
\hline Manihot dichotoma Ule & 25 & 0.14 & $58.82 \%$ & 8 & 0.21 & 1.55 & $\mathrm{fr}, \mathrm{ct}$ \\
\hline Maytenus rigida Mart. & 59 & 0.62 & $05.88 \%$ & 0 & 0 & 0 & fr,me \\
\hline Mimosa ophthalmocentra Mart ex Benth. & 44 & 0.59 & $64.71 \%$ & 20 & 0.52 & 3.33 & fr,fu,ct,tc \\
\hline Mimosa tenuiflora (Willd.) Poir. & 47 & 0.86 & $82.35 \%$ & 3 & 0.08 & 0.67 & fr,fu,ct, \\
\hline Myracrodruon urundeuva Allemão & 51 & 1.59 & $82.35 \%$ & 3 & 0.08 & 0.67 & fr,fu,ct,me,vt,tc \\
\hline Poincianella pyramidalis Tul. & 39 & 2.24 & $88.24 \%$ & 1172 & 30.25 & 21.95 & fr,fu,ct, \\
\hline $\begin{array}{l}\text { Pseudobombax marginatum (A.St.-Hil.,Juss.\& Cambess.) } \\
\text { A. Robyns }\end{array}$ & 45 & 0.24 & $17.65 \%$ & 2 & 0.05 & 0.44 & me,vt \\
\hline Sideroxylon obtusifolium (Roem. \& Schult.) T.D. Penn. & 55 & 1.76 & $58.82 \%$ & 0 & 0 & 0 & fo,fr,ct,me,tc \\
\hline Spondias tuberosa Arruda & 38 & 1.52 & $35.29 \%$ & 2 & 0.05 & 0.44 & fo,fr,fu \\
\hline Ximenia americana $\mathrm{L}$. & 58 & 0.86 & $0 \%$ & 0 & 0 & 0 & me,vt \\
\hline Unidentified (louro) & 30 & 0.86 & $05.88 \%$ & 0 & 0 & 0 & tc \\
\hline
\end{tabular}




\section{DISCUSSION}

PRIORITY SPECIES FOR CONSERVATION AND COMPARISON

AMONG INDEXES

The importance of the inventory of vegetation in the present study, besides providing information to compose the conservation priority index, is the possibility to observe in the areas of resources achievement which species are suffering pressure of use, as well as registering their distribution and presence in the areas of caatinga vegetation. These informations are essential for conservationist actions. In Barrocas and Cachoeira, were observed in the phytossociological inventory that some species with individuals completely severed and others with signs of regrowth, as the $P$. pyramidalis, $M$. urundeuva, A. pyrifolium, S. brasiliensis and $C$. blanchetianus. These species were considered for conservationist actions in these communities. This indication is supported by these findings in the vegetation, confirming their present use, besides being widely versatile and used.

In Soledade were registered (in the vegetation) evidences of current use of species mentioned in the interviews. Lucena et al. (2007b) performing an inventory of the vegetation in the city of Caruaru (Pernambuco) also found species cited by people as useful, with individuals showing extraction signs in the forest, as Cordia trichotoma (Vel.) Arráb. ex Steud. which is used in the handicraft manufacture, and showed their individuals with signs of selective cut in the vegetation.

Literature has shown the necessity of adopting conservation priorities for some species from Caatinga, as $M$. urundeuva, $P$. pyramidalis, $C$. blanchetianus, $S$. brasiliensis, $Z$. joazeiro, $S$. obtusifolium, C. leptophloeos and C. quercifolius (Albuquerque and Oliveira 2007, Oliveira et al. 2007, Albuquerque et al. 2009). These species were evidenced in Soledade through three studied indexes, confirming the indication of the same ones for conservationist actions. However, some deserve more immediate attention and others do not. S. Brasiliensis and M. urundeuva, for example, are enclosed in the official list of the extinguishing threatened species through the Normative Instruction $\mathrm{N}^{\mathrm{o}} 06$ of September $23^{\text {rd }}$ 2008 of the Environment Ministry. In the case of C. leptophloeos, Oliveira et al. (2007) pointed out the necessity regarding its conservation, but not in immediate way.

The species which are indicated in the communities from Soledade with conservation priority were highlighted in literature as versatile species, presenting utility in more than one category of use, as much as lumber or not-lumber (Albuquerque and Andrade 2002a, b, Albuquerque et al. 2005, Ferraz et al. 2006, Albuquerque and Oliveira 2007, Florentino et al. 2007, Lucena et al. 2007a, b, 2008, Sá and Silva et al. 2009). This versatility favors further the pressure of use on them, being necessary specific studies to evaluate the real situation of the same ones in the forests of the region, as well as how to extract them.

A. pyrifolium, $P$. pyramidalis and $C$. blanchetianus were the ones with highest values in the list of the use value and in the inventory in situ. However, they are widely found in all areas of vegetation in the communities, what led them to lower scores in the conservation priority index. Because this abundance in the vegetation, it can assume that they do not need immediate conservationist attention. Literature evidenced that factors as the species availability in the vegetation are very important to define conservation priorities, which are used to compose the indexes created in this sense (Dhar et al. 2000, Oliveira et al. 2007). Therefore, prudence is necessary to assert that the species with higher use value or greater frequency in inventories in situ are those with higher conservation priority, due these indexes do not take into consideration the resource availability.

In Soledade, the use value and the inventory in situ have tended to prioritize widely used species, 
however, available in the vegetation. This trend may be explained by the hypothesis of ecological appearance (Phillips and Gentry 1993, Lucena et al. 2007b), which predicts that the more available a resource in the vegetation is bigger will be its use. This hypothesis can be of great value in the conservationist indications, for helping to understand this relation of use and the resource availability.

A study about the abundance and distribution of the useful species in Caatinga carried out in 20 areas from Northeast Brazil registered a wide distribution of some indicated species in the present study with conservationist necessities (Santos et al. 2008): A. pyrifolium and M. urundeuva (registered in 17 of these areas), A.colubrina and J. mollissima (16), C. leptophloeos and P. pyramidalis (15), B. cheilantha (14), S. brasiliensis (13), and the others in few areas. Another point presented by Santos et al. (2008) was the versatility of these species, presented in average more than five use categories, the same occurring in the present study. These information are important, because it provided data of the distribution of these species in a bigger universe in the Caatinga, that may be used in the analysis of the necessity or not, in considering a species as worthy of conservation priorities or, if the conservationist attention is restricted to local level, or can be considered as regional level.

Besides the species distribution, it is also necessary to analyze its abundance in the local vegetation, because a species can be well distributed in the Caatinga, and being registered in all inventories of the vegetation. However, it can show few individuals, like M. urundeuva, as shown in the study of Santos et al. (2008). It was registered in 17 areas, however presenting low individuals number, maximum of 49 individuals in the same area. This trend was confirmed in Soledade, where this species presented just three individuals in each performed inventory, from Cachoeira and Barrocas.

Observing the species to analyze the list offered by the index of the use value and the inventory in situ, it has been observed a similarity regarding the most important species, possibly because both are related to information of real use of the plants, independently of the category in which are involved. That differs from the conservation priority index, which also incorporated phytossociological information and the collection frequency. Monteiro et al. (2008) in a comparative study of methods, also observed a similarity between general interviews, with which it was calculated the use value and the inventory in situ.

The list of the most important species in the conservation priority index differed from the one found by the use value and by the inventory in situ due the fact that rare species in the vegetation received high scores in the IPC, showing more limited uses, thus receiving lower scores in the use value and in the inventory in situ. An example is $X$. Americana that is used in the local medicine; however its individuals are rare in the forests from the two communities. This panorama of difference in the list of the conservation priority index regarding the use value, and the inventory in situ was equal in Barrocas and Cachoeira.

From the ten valued species in Soledade through the conservation priority index, three had been valued with highest scores in Carurau, where Oliveira et al. (2007) applied a priority index similar to the one adopted in the present study. The species were $Z$. juazeiro, S. brasiliensis and M. urundeuva. Dzerefos and Witkowski (2001) also presented them in their conservation priority index as species with greater scores, those that are scarcely found in the region, mainly because the strong extraction pressure.

A limitation of the conservation priority index, as much in the present study, as in the one of Dzerefos and Witkowski (2001) and Oliveira et al. (2007), it is the lack of an appropriate score to analyze the amount of resources taken from the vegetation. Without it, any consideration of conservationist matrix is more limited. It has been suggested, for future studies, this aspect of the use 
of a species to be considered in the calculation of this index, taking into consideration the different categories of use that the researcher comes across in the context of the studied community.

Another question that must be observed when is necessary to identify the species with conservation priority, mainly when it uses quantitative indexes for such, is the perspective of whom is observing such plants; it is the researcher or the studied population. This observation has been neglected in the indexes calculation. Perhaps it would be interesting to have a test with such parameter in future studies. Depending on this point of view, it is possible to get a different list for such priorities. In Soledade, the indexes pointed out with necessities of actions focused toward the conservation of abundant species in the local vegetation. Which in the inhabitants' point of view, the same species can be used without concern for being abundant. For example the case of $C$. pyramidalis which was indicated by $85 \%$ of the informants from Barrocas and $75 \%$ from Cachoeira as a species that does not deserve any concern.

Passing through this specific analysis in each community, for a comparison between them, a difference in the list of the conservation priority index was observed. Observing the list presented in each community, it was verified that the one from Cachoeira evidenced rare species in the forests from the community, however more frequent in the ones from Barrocas, as $S$. obtusifolium, $X$. americana, $B$. cheilantha and $M$. rigida. The scarcity of a species in the vegetation makes its score in the index to receive the higest value, thus favoring this distinction.

A factor that may had led to a higher register of species in Barrocas was the way how the inventory of the vegetation was carried out. As in this community, there were only private farms, the inventory was divided in four areas of distinct farms, differing from Cachoeira in which was carried through in one same area without the division necessity. In this sense, in Barrocas there were allocated plots in areas close to intermittent rivers, as in areas of intense collection of vegetal resources, in areas with sandy soil, and others with clay and stony soil. This bigger diversity in Barrocas was influenced by this vegetation mosaic, different from Cachoeira that was homogeneous regarding these features.

\section{CONCLUSION}

The application of the use value, inventory in situ and conservation priority index in Soledade has allowed selecting a group of species needing conservationist actions, which mostly also have been emphasized in other studies performed in the Caatinga focusing the conservation. This emphasized their success, strengthening their use in studies aiming to recognize species which require such priorities. However, the ideal would be the triangulation of different methods, thus as shown in the present study, because each one comes from a different premise.

In the case of the use value and the inventory in situ, it was just taken into consideration, information about the real use of species. The conservation priority index attached information about the availability in the vegetation with collection frequency, for example.

As the present study aimed to analyze the best technique to identify species which were needing conservationist actions, and has obtained different results among the chosen methods, it is suggested the use of methods that unite their analysis, both ethnobotanical aspects or ecological, as it happens in the plants list production of the conservation priority index, proving to be more efficient to identify rare species in local vegetation. The VU and the inventory in situ proved to be more efficient to identify the most used and known species in the communities, however without an analysis of these plants in the local vegetation. 


\section{RESUMO}

O presente estudo avaliou três métodos de análise de dados buscando identificar o que seria mais apropriado para obter informações visando à conservação, selecionando o valor de uso (VU), inventário in situ e o índice de propriedade de conservação (IPC). Este foi desenvolvido no Nordeste do Brasil, sendo entrevistados os chefes de família (46 informantes). O VU foi calculado considerando apenas o uso efetivo das plantas, o inventário in situ foi analisado por meio da frequência de ocorrência das espécies nas residências, e o IPC, combinando dados etnobotânicos e fitossociológicos. Observou-se um elenco semelhante das espécies indicadas pelo VU e inventário in situ, sendo diferente do elenco do IPC. Como este estudo procurou analisar a melhor técnica para identificação de espécies que precisam de ações conservacionistas, e por ter obtido resultados diferentes entre os métodos escolhidos, sugere-se o uso de métodos que reunam em suas análises tanto aspectos etnobotânicos quanto ecológicos, como por exemplo a lista de plantas feitas a partir do índice de prioridade de conservação, que demonstrou ser mais eficiente para identificar espécies raras na vegetação local. Já o VU e o inventário in situ foram mais eficientes para identificar as espécies mais conhecidas e utilizadas nas comunidades, sem no entanto, analisar, essas plantas na vegetação local.

Palavras-chave: biodiversidade, caatinga, inventário in situ, índice de prioridade de conservação, valor de uso.

\section{REFERENCES}

AlbuQUeRQue UP AND ANDRADE LHC. 2002a. Conhecimento botânico tradicional e conservação em uma área de Caatinga no Estado de Pernambuco, Nordeste do Brasil. Acta Bot Bras 16: 273-285.

Albuquerque UP AND ANDRADE LHC. 2002b. Uso de recursos vegetais da Caatinga: o caso do agreste do estado de Pernambuco (Nordeste do Brasil). Interciencia 27: 336-345.

AlbuQuerque UP, ANDrade LHC AND Silva ACO. 2005. Use of plant resources in a seasonal dry forest (Northeastern Brazil). Acta Bot Bras 19(1): 27-38.

AlbuQuerque UP, ARAujo TAS, RAmos MA, NASCIMENTO VT, LUCENA RFP, MONTEIRO JM, ALENCAR N AND ARAÚJO EL. 2009. How ethnobotany can aid biodiversity conservation reflections on investigations in the semi-arid region of NE Brazil. Biodivers Conserv 18: 127-150.
AlbuQUeRQue UP AND LUCENA RFP. 2005. Can apparency affect the use of plants by local people in tropical forests? Interciencia 30: 506-511.

ALBUQUERQUe UP, LUCENA RFP AND ALENCAR NL. 2010b. Métodos e técnicas para a coleta de dados etnobiológicos. In: ALBUQUERQUE UP, LUCENA RFP AND CUNHA LVFC (Eds), Métodos e técnicas na pesquisa etnobiológica e etnoecológica. NUPEEA, Recife, p. 38-64.

ALBUQUERQUE UP, LUCENA RFP AND LINS NETO EMF. 2010a. Seleção dos participantes da pesquisa. In: ALBUQUERQUE UP, LUCENA RFP AND CUNHA LVFC (Eds), Métodos e técnicas na pesquisa etnobiológica e etnoecológica. NUPEEA, Recife, p. 23-37.

ALBUQUERQUE UP, LUCENA RFP, MONTEIRO JM, FLORENTINO ATN AND ALMEIDA CFCBR. 2006. Evaluating two quantitative ethnobotanical techniques. Ethn Res \& Appl 4: 51-60.

AlBUQUeRQue UP AND OlIVEIRA RF. 2007. Is the use-impact on native caatinga species in Brazil reduced by the high species richness of medicinal plants? J Ethnopharmacol 113: $156-170$

ARAÚJO EL AND FERRAZ EMN. 2010. Análise da vegetação nos estudos etnobotânicos. In: Albuquerque UP et al. (Eds), Métodos e técnicas na pesquisa etnobiológica e etnoecológica. NUPEEA, Recife, p. 223-253.

ARAÚJO HFP, LUCENA RFP AND MOURÃO JS. 2005. Prenúncio de chuvas pelas aves na percepção de moradores de comunidades rurais no município de Soledade - PB, Brasil. Interciencia 30: 764-769.

AtLAs GeográFico do Estado da PARAíbA. 1985.

Ayres M, Ayres JRM, Ayres DL and SANTOS AS. 2003. BioEstat 3.0. Aplicações estatísticas nas áreas das ciências biológicas e médicas. Belém, Pará.

BREWER DD. 2002. Complementary interviewing techniques to maximize output in free listing tasks. Field Meth 14: 108-118.

DALLE SP AND POTVIN C. 2004. Conservation of useful plants: an evaluation of local priorities from two indigenous communities in eastern Panama. Econ Bot 58: 38-57.

Dhar U, RAWAL RS AND UPRETI J. 2000. Setting priorities for conservation of medicinal plants - a case study in the Indian Himalaya. Biol Conser 95(1): 57-65.

Dzerefos CM AND WiTKOWSKI ETF. 2001. Density and potential utilization of medicinal grassland plants from Abe Bailey Nature Reserve, South Africa. Biod Cons 10: $1875-1896$.

Ferraz JSF, AlbuQuerque UPA AND MEUNIER IMJ. 2006. Valor de uso e estrutura da vegetação lenhosa às margens do Riacho do Navio, Floresta, PE, Brasil. Acta Bot Bras 20(1): 125-134

Florentino ATN, ARAúJo EL AND ALBUQUERQUe UP. 2007. Contribuição de quintais agroflorestais na conservação de plantas da Caatinga, município de Caruaru, PE, Brasil. Acta Bot Bras 21(1): 37-47.

Galeano G. 2000. Forest use at the Pacific Coast of Chocó, Colômbia: a quantitative approach. Econ Bot 54: 358-376. 
GAUGRIS JY AND VAN ROOYEN MW. 2006. Questionnaires do not work? A comparison of methods used to evaluate the structure of buildings and wood used in Rural Households, South Africa. Ethn Res Appl 4: 119-131.

GAVIN MC AND ANDERSON GJ. 2005. Testing a rapid quantitative ethnobiological technique: first steps towards developing a critical conservation tool. Econ Bot 59: 112-121.

HANAZAKI N, SOUZA VC AND RodRIGUES RR. 2006. Ethnobotany of rural people from the boundaries of Carlos Botelho State Park, São Paulo State, Brazil. Acta Bot Bras 20(4): 899-909.

HOFFMAN B AND GALLAHER T. 2007. Importance indices in ethnobotany. Ethn Res Appl 5: 201-218.

Kristensen M AND BAlslev H. 2003. Perceptions, use and availability of woody plants among the Gourounsi in Burkina Faso. Biodivers Conserv 12: 1715-1739.

KVist LP, ANDERSEN MK, StAGEgAard J, Hesselsoe M AND LLAPAPASCA C. 2001. Extraction from woody forest plants in flood plain communities in Amazonian Peru: use, choice, evaluation and conservation status of resources. Forest Ecol Manage 150: 147-174.

LA TORRE-CuAdros M AND IslebE GA. 2003. Traditional ecological knowledge and use of vegetation in southeastern Mexico: a case study from Solferino, Quintana Roo Biodivers Conserv 12: 2455-2476.

LuCEnA RFP, Albuquerque UP, Monteiro JM, Almeida CFCBR, FLORENTINO ATN AND FERRAZ JSF. 2007a. Useful plants of the semi-arid northeastern region of Brazil - a look at their conservation and sustainable use. Envir Monit Asses 125: 281-290.

LUCENA RFP, ARAUJO EL AND ALBUQUERQUE UP. 2007b. Does the use-value of woody plants of the Caatinga (Northeastern Brazil) explain their local availability. Econ Bot 61: 347-361.

LUCENA RFP, ARAÚJO HFP, MOURÃO JS AND ALBUQUERQUE UP. 2005. A flor chegou, chuva avisou: metereologia popular no semi-árido paraibano. In: ALVES AGC, LUCENA RPF AND ALBUQUERQUE UP (Eds), Atualidades em Etnobiologia e Etnoecologia. NUPEEA, Recife, p. 171-182.

LUCENA RFP, NASCIMENTO VT, ARAUJO EL AND ALBUQUERQUE UP. 2008. Local uses of native plants in an area of caatinga vegetation (Pernambuco, NE-Brazil). Ethn Res \& Appl 6: 3-13.

LYKKE AM, KRISTENSEN MK AND GANABA S. 2004. Valuation of local use and dynamics of 56 woody species in the Sahel. Biodivers Conserv 13: 1961-2004.

Medeiros PM, ALmeida ALS, Lucena RFP, SOUTO FJB AND AlBUQUERQue UP. 2010. Uso de estímulos visuais na pesquisa etnobiológica. In: ALBUQUERQUE UP, LUCENA RFP AND CUNHA LVFC (Eds), Métodos e técnicas na pesquisa etnobiológica e etnoecológica. NUPEEA, Recife, p. 151-169.
MONTEIRO JM, LUCENA RFP, ALENCAR NL, NASCIMENTO VT, ARAÚJO TAS AND AlbUQUERQUE UP. 2008. When intention matters: comparing three ethnobotanical data collection strategies. In: ALBUQUERQUE UP AND RAMOS MA (Orgs), Current Topics in Ethnobotany. Research Signpost, India, p. 113-124.

Mueller-Dumbois D AND Ellenberg H. 1974. Aims and methods os vegetation ecology. New York: J Wiley \& Sons, $574 \mathrm{p}$.

Oliveira RLC, Lins-Neto EMF, Araujo EL AND ALBUQUERQUE UP. 2007. Conservation priorities and population structure of woody medicinal plants in area of Caatinga vegetation (Pernambuco State, NE Brazil). Environ Monit and Asses 132: 189-206.

PhILlIPS O AND GENTRY AH. 1993. The useful plants of Tambopata, Peru: II additional hypothesis testing in quantitative ethnobotany. Econ Bot 47: 33-43.

Ramos MA, Medeiros PM, Almeida ALS, Feliciano ALP AND ALBUQUeRQUe UP. 2008a. Use and knowledge of fuelwood in an area of caatinga vegetation in NE Brazil. Biomass Bioenerg 32: 510-517.

Ramos MA, Medeiros PM, Almeida ALS, Feliciano ALP AND ALBUQUeRQue UP. 2008b. Can wood quality justify local preferences for firewood in an area of caatinga (dryland) vegetation. Biomass Bioenerg 32: 503-509.

Rossato SC, Leitão-FILho HF AND Begossi A. 1999. Ethnobotay of Caiçaras of the Atlantic Forest Coast (Brazil). Econ Bot 53: 387-395.

SÁ AND Silva IMM, MARANGON LC, HANAZAKI N AND ALBUQUERQUE UP. 2009. Use and knowledge of fuelwood in three rural caatinga (dryland) communities in $\mathrm{NE}$ Brazil. Enviro Develop Sustain 11: 833-852.

SANTOS JP, ARAÚJO ELAND ALBUQUERQUEUP. 2008. Richness and distribution os useful Woody plants in the semi-arid region os northeastern Brazil. J Arid Environ 72: 652-663.

StAGEGAARD J, SorEnSENB M AND KVIST LP. 2002. Estimations of the importance of plant resources extracted by inhabitants of the Peruvian Amazon flood plains. Persp Plan Ecol Evol System 5: 103-122.

Sebrae-PB. 1998. Soledade. Série Diagnóstico. SócioEconômico. João Pessoa, Paraíba.

ZAR JH. 1996. Bioestatistical analysis. Prentice-Hall, London. 